\title{
Physical education of students, considering their physical fitness level
}

Andres A.S.

\author{
National University of Lviv's Polytehnyka, Ukraine
}

\begin{abstract}
Purpose:

to determine effectiveness of students' physical education program, mainly directed at development of leading physical qualities.

Material: $\quad 100$ students participated in experiment. In control group $(n=50)$ all physical qualities were trained equally. In experimental group $(n=50)$ loads were directed at training of leading (better trained) physical qualities.

Results: $\quad$ we detected higher physical culture-sport activity of students in conditions of the author's program's application Higher health related effectiveness of experimental program was illustrated also by its facilitating increasing the students' weekly activity. The found facts prove effectiveness and importance of those physical loads' priority application in trainings process, to which students have genetic bent.

Conclusions: demand and timeliness of individual-typological approach is conditioned by the following: distinctions in students physical fitness; personalities' specificities of students' reactions to external factors and physical loads.

$\begin{array}{ll} & \text { physical fitness; personalities' specificities of students' reactions to external factors and physical loads. } \\ \text { Keywords: } & \text { physical qualities, physical education, students, training program, health related influence, physical activity. }\end{array}$
\end{abstract}

\section{Introduction}

Ideas of pedagogic process's humanization and democratization, conception of centralized on students education envisage consideration of individual features of every person. The problem of individual approach in physical education (PE) is very relevant to day. Timeliness of individual approach's application and demand in it are conditioned by distinctions in students' physical fitness and their personalities' aspects of reacting to external factors and physical loads. Different physical fitness and interests; students' intellectual and physical potentials result in different temps of their mastering the required material. Application of PE means and methods often does not meet students' individual features. It weakens health related influence of trainings and can negatively impact on students' health; slow the temps of their physical development and result in loss of interest to PE classes. Consideration of organism's individual features and condition permits to select adequate PE means and ensure harmonious development of motor abilities. Working out of ways for perfection of the best individual qualities will permit to choose own way for opening individuality, for maximal self-perfection and self-realization. Such approach to PE reduces the danger of physical overloads and facilitates health related effectiveness of physical exercises' practicing as well as reliable mastering of motor skills and their perfection.

Demand in individual approach to education was stressed on by outstanding scientists and pedagogues. Individual-typological approach in $\mathrm{PE}$ is preceded by determination of criteria for separate individuals' combining in certain homogenous groups [17, 34, 35]. In PE practice specialists offer to widely use indicators of physical fitness as criteria for students' distribution into homogenous groups. They substantiate their opinion by the fact that physical fitness can be measured more precisely than other parameters and informative value of such indicators increases with age. Methodic of their determination does not require great effort; measurement procedure is rather simple and standard. Such approaches

(C) Andres A.S., 2017

doi:10.15561/20755279.2017.0301 can be used in students' PE [17, 19, 25].

Scientific researches on comparing of different training programs for perfection of "leading” or "lagging” sides of physical fitness are most often conducted in the following kinds of sports: rugby [2], wrestling [3, 26, 27], skiing [4], football [5], multiathlon [6]; arm-wrestling [32]. In most of cases specialists doubt about purposefulness of training of those physical qualities that are not genetically preconditioned.

On example of contingent of 16 years age (swimming) effectiveness of stage-by stage training process was proved. Correlation of means at initial stage of training was within: $40 \%$ - leading qualities and $60 \%$ - lagging behind qualities. At final stage such correlation is: $55 \%-$ leading qualities and 45\% -weaker qualities. [1].

One of possible ways of PE perfection at higher educational establishments is implementation of programs with new, non traditional kinds of sports: health related hiking [11], fitness [18, 31], kick-boxing and aerobics [20]. Recent time scientists devote their works to effectiveness of sport-oriented PE programs and working out of the models, based on informational technologies [8, 22]. Practicing the chosen kind of sport, students manifest interest to them $[10,36]$. They are much more active [13, 33], that facilitates development of morel-will qualities [9]. Often students do not want to achieve high sport results. But development of leading physical qualities permits to open genetically embedded physical qualities and train them. It ensures self-satisfaction $[12,23]$.

In special literature there are a few publications, devoted to criteria of students' individual-typological PE, considering their physical fitness level. For formation homogenous groups specialists recommend to consider the following: psychological indicators [14, 29]; characteristics of nervous system [20, 30]; psychophysiological indicators [7, 28]; bio-medical indicators (biological age) [15, 24], somatic health and diseases [16]). All specialists theoretically substantiated and proved practically that individual approach to $\mathrm{PE}$ is much more effective than traditional. In particular they point that with application of individually differentiated trainings students-sportsmen's functional potentials expand, their 
functional and psycho-physiological indicators improve and somatic health strengthens. Besides, physical workability and fitness increase.

Thus, analysis of literature data showed contradictory character of information about purposefulness of priority development of leading (strong) or lagging behind (weak) physical qualities. Besides, we did not find any information about orientation of PE process for young, not trained persons. The absence of such information increases probability of physical overloads and traumas in students at physical culture lessons. It results in violation of main education principles (including physical education) and thus, does not facilitate approaching of domestic education to European standards. Information about purposefulness of priority development of students' leading (strong) physical qualities will facilitate increase of PE effectiveness in higher educational establishments.

The purpose of the research: is to determine effectiveness of students' physical education program, mainly directed at development of leading physical qualities.

\section{Material and methods}

Participants: in pedagogic experiment 100 students participated. 50 of them were experimental group (EG) and 50 - control group (CG).

Organization of the research: for determination of the program's effectiveness we carried out pedagogic experiment. In control group $(n=50)$ all physical qualities were trained equally. In experimental group $(n=50)$ loads were directed at training of leading (better trained) physical qualities. At PE trainings we used the means of light athletic. Practicing and improvement of light athletic exercises were realized at open sport sites and indoors.

At the beginning of academic year (in October) for determination of the most developed physical qualities we carried out testing of physical fitness by norms, envisaged by PE academic program. During all academic year (56 hours from total 64), in the main part of each training students fulfilled the tasks, worked out for development of one from 4 physical qualities (strength, quickness, dexterity or endurance).

Statistical analysis: confidence of differences between mean arithmetic group indicators we used Student's t-test (for related and not related samples).

\section{Results}

Testing results (see table 1) permitted to see that at the beginning of academic year students' arm strength was at the lowest level. Chin ups and pressing ups on parallel bars results were assessed by the lowest marks (0-1 points). Forward bending results were also low in both groups that witnessed about bad flexibility. Relatively higher were the results of 1000 meters' run and torso rising in sitting position (3-4 points). It witnessed about above average endurance and power endurance of abdominal muscles in most of students.

During pedagogic experiment the highest increment of test results were in indicators of flexibility $(60.2 \%$
(EG) and 38.6\% (CG)). With it confident improvement was registered in both groups. Significant increments of indicators can be explained by their very low initial level. It should be noted that in EG students there happened noticeable increase of flexibility from low to average. After experiment distinctions in flexibility were confident in favor of EG.

Rather substantial was increment of power endurance indicators of students' arms (in chin ups: $59.9 \%$ and $28.0 \%$ and in pressing ups on parallel bars: $32.6 \%$ and $42.4 \%$ accordingly). In experiment significant and statistically confident increase of EG students' results brought to substantial increase of marks (up to satisfactory) for this control exercises. In CG improvements were not so noticeable. By pressing ups on parallel bars' results confident improvements happened in both groups. But in EG results were higher. Confident differences between CG and EG indicators showed that experimental program is more effective in training of students' arms strength.

In indicators of endurance and dexterity positive changes also happened, though comparatively less by their values (3.2\% in both groups and 5.0\% and 3.1\% accordingly in EG and $\mathrm{CG}$ ). In experiment insignificant changes took place in 100 meters' run $(1.8 \%$ and $2.1 \%)$. Though, differences between EG and CG indicators were not proved statistically. These differences approached to the borders of statistical confidence. Relatively higher improvements of EG students' results witness about tendency to substantial increase of endurance, speedpower endurance and dexterity.

In general, increment of physical fitness results of EG students was by 55.5\% higher than in control group students. It is one more proof of effectiveness of trainings with priority development of "leading" physical qualities.

Analysis of PE classes' attendance by both groups' students showed shortening of classes' missing due to diseases in both groups. It witnesses about reduction of morbidity in EG and about rising of interest in PE classes. PE classes with priority development of «leading" physical qualities resulted in increase of students' participation in sport competitions (in the role of referees - controllers) and directly as participants. It facilitated substantial increase of students' motor activity. It should be noted that PE in higher educational establishments is assessed considering results of tests for physical fitness and students' participation in mass-sport and health related physical culture measures. In experiment we observed noticeable improvement of educational progress (in PE) indicators: experimental group students $-73.3 \%$. It is nearly by quarter (23.4\%) better than in control group (49.9\%).

\section{Discussion}

Our data confirmed higher effectiveness of individual approach in students' $\mathrm{PE}[1,13,23]$. Alongside with it, it is pointed [12,] that it is necessary to work out new methodic for determination of students individual abilities' level, which would meet modern innovative and informationaltechnological approaches. Such methodic would facilitate 
Table 1. Results of students' fulfillment of tests for physical fitness

\begin{tabular}{|c|c|c|c|c|c|c|c|c|}
\hline Test exercises & Groups & $\begin{array}{l}\text { Beginning of } \\
\text { experiment (C } \\
2015 \text { ) } \\
\text { Result, } x \pm m\end{array}$ & $\begin{array}{l}\text { dagogic } \\
\text { tober }\end{array}$ & $\begin{array}{l}\text { End of pedag } \\
\text { experiment ( } \\
\text { 2015) } \\
\text { Result, } x \pm m\end{array}$ & Points & $\begin{array}{l}\text { Increment } \\
\text { of results, } \\
\%\end{array}$ & $\begin{array}{l}\text { Confidence } \\
\text { of } \\
\text { increments- } \\
t_{\text {beg-end- }} *\end{array}$ & $\begin{array}{l}\text { Confidence } \\
\text { of } \\
\text { increments } \\
\text { after } \\
\text { experiment } \\
\text { EG }_{\text {end }}-\text { CG }_{\text {end }} * *\end{array}$ \\
\hline \multirow{2}{*}{$\begin{array}{l}1000 \text { meters } \\
\text { run, sec. }\end{array}$} & EG & $4.14 \pm 0,07$ & 4 & $4.06 \pm 0,59$ & 4 & 3.2 & $>0.05$ & \multirow{2}{*}{$>0.05$} \\
\hline & CG & $4.17 \pm 0,07$ & 2 & $4.09 \pm 0,09$ & 4 & 3,2 & $>0.05$ & \\
\hline \multirow{2}{*}{$\begin{array}{l}100 \text { meters } \\
\text { run, sec. }\end{array}$} & EG & $14.42 \pm 0.02$ & 2 & $14.17 \pm 0.03$ & 3 & 1.8 & $>0.05$ & \multirow{2}{*}{$>0.05$} \\
\hline & CG & $14.42 \pm 0.02$ & 2 & $14.27 \pm 0.03$ & 3 & 2.1 & $>0.05$ & \\
\hline \multirow{2}{*}{$\begin{array}{l}\text { Long jump } \\
\text { from the spot, } \\
\mathrm{cm}\end{array}$} & EG & $220.34 \pm 0.03$ & 2 & $234.00 \pm 0.03$ & 3 & 6.1 & $>0.05$ & \multirow[b]{2}{*}{$>0.05$} \\
\hline & CG & $224.34 \pm 0.06$ & 3 & $231.00 \pm 0.18$ & 3 & 2.9 & $>0.05$ & \\
\hline \multirow{2}{*}{$\begin{array}{l}\text { Shuttle run } \\
4 \times 9 \mathrm{~m} \text {, sec. }\end{array}$} & EG & $9.81 \pm 0.34$ & 2 & $9.32 \pm 0.08$ & 3 & 5.0 & $>0.05$ & \multirow{2}{*}{$\leq 0.05$} \\
\hline & CG & $9.70 \pm 0.92$ & 3 & $9.40 \pm 0.46$ & 3 & 3.1 & $>0.05$ & \\
\hline \multirow{2}{*}{ Chin ups, times } & EG & $7.82 \pm 0.52$ & 0 & $12.51 \pm 0.04$ & 3 & 59.9 & $<0.05$ & \multirow{2}{*}{$<0.05$} \\
\hline & CG & $7.32 \pm 0.82$ & 0 & $9.42 \pm 0.94$ & 1 & 28.0 & $>0.05$ & \\
\hline \multirow{2}{*}{$\begin{array}{l}\text { Forward torso } \\
\text { bending from } \\
\text { sitting position, } \\
\mathrm{cm}\end{array}$} & EG & $8.45 \pm 0.07$ & 1 & $13.54 \pm 0.92$ & 3 & 60.2 & $<0.05$ & \multirow[b]{2}{*}{$<0.05$} \\
\hline & CG & $8.15 \pm 0.07$ & 1 & $11.3 \pm 0.08$ & 2 & 38.6 & $<0.05$ & \\
\hline \multirow{2}{*}{$\begin{array}{l}\text { Torso rising in } \\
\text { sitting posi- } \\
\text { tion for } 1 \text { min., } \\
\text { times }\end{array}$} & EG & $42.6 \pm 1.53$ & 3 & $48.2 \pm 1.24$ & 4 & 13.1 & $>0.05$ & \multirow[b]{2}{*}{$>0.05$} \\
\hline & CG & $42.6 \pm 1.53$ & 3 & $45.2 \pm 1.24$ & 3 & 6.1 & $>0.05$ & \\
\hline \multirow{2}{*}{$\begin{array}{l}\text { Pressing ups on } \\
\text { parallel bars, } \\
\text { times }\end{array}$} & EG & $9.07 \pm 0.09$ & 1 & $12.03 \pm 0.06$ & 3 & 32.6 & $<0.05$ & \multirow[b]{2}{*}{$<0.05$} \\
\hline & CG & $7.17 \pm 0.95$ & 0 & 10. $21 \pm 0.76$ & 2 & 42.4 & $<0.05$ & \\
\hline \multirow{2}{*}{ Total of points } & EG & - & 15 & - & 26 & 181.9 & - & \multirow{2}{*}{-} \\
\hline & CG & - & 14 & - & 21 & 126.4 & - & \\
\hline
\end{tabular}

Legend: * - t beg.end - between initial and final results; ** - EGend-CGend - between final results of experimental and control groups' students (measured after pedagogic experiment).

quick and correct determination of student's individual abilities; his/her psycho-physiological and psychological features. Thus, it could be possible to find potentially strong students, who, during study at HEE, can cover the way from beginner to elite sportsman.

The received by us results proved the data of specialists [1] that PE program shall be oriented on targeted development of leading physical qualities. Such program is more effective than the program, envisaging equal development of all physical qualities. That is why, in organization of PE process it would be rational to orient on training of leading physical qualities. Similar results were received on contingent of schoolchildren, who did not practice sports, as well as on contingent of sportsmenbeginners and sportsmen of different sport categories in different kinds of sports (motor activity): multiathlon [6] and swimming [1]. These authors considered different indicators (physical fitness, physical workability, central haemo-dynamic, aerobic endurance, morbidity, general activity). Thus, we can assume that program on development of leading physical qualities is more effective than other programs.
Our data also proved that trainings with accent on development of leading physical qualities differ by health related influence on organism. We also confirmed [12] that in students age prevailing development of stronger physical qualities positively impacts on students' physical culture/sport activity.

\section{Conclusions}

By total increment of all tests' results PE program for students with prevailing development of stronger physical qualities is more effective $(181.9 \%, \mathrm{p}<0.05)$ than the program, oriented on equal development of all physical qualities (126.4\%). Higher health related effectiveness of experimental program is illustrated by its ability to facilitate increase of volumes of students' weekly physical, health related physical culture and mass sports activity. It concerns physical loads, to which students are genetically pre-conditioned.

\section{Conflict of interests}

The author declares that there is no conflict of interest. 


\section{References}

1. Novikov AO, Novikova TV. Individualizaciia programm plavatel'noj podgotovki uchashchikhsia professional'nykh uchebnykh zavedenij [Individualization of swimming training programs for vocational colleges' students]. Vestnik sportivnoj nauki, 2013; 1:34-38. (in Russian)

2. Pasko VV. Perfection of educational-training process on the basis of account of parameters special physical preparedness of rugby-players. Physical education of students, 2014; 18(3): 49-55. doi:10.6084/m9.figshare. 972852

3. Latyshev SV, Korobeynikov GV. Approach of the systems to problem of individualization of training of fighters. Physical education of students, 2013; 17(5): 65-68. doi:10.6084/ m9.figshare.771109

4. Vorfolomeeva LA. Individualization of training process as a leading construction of skiers' training component in preparation for higher achievements. Physical education of students, 2013; 17(4): 15-18. doi:10.6084/ m9.figshare.669672

5. Berezka SM, Chopilko TG. An investigation of individual functionality football referees qualifications. Physical education of students, 2014; 18(6): 8-12. doi:10.15561/20755279.2014.0602

6. Andrij Andres, Mikhajlo Linec', Ivan Vojtovich. Dinamika special'noi pidgotovlenosti bagatoborciv vijs'kovosportivnogo kompleksu uprodovzh pidgotovchogo periodu richnogo makrociklu [Special fitness dynamic of multiathlon athletes of military sport complex during preparatory period of annual macro-cycle]. Moloda sportivna nauka Ukraini, 2007;3: 6 -12. (in Ukrainian)

7. Barybina LN, Kolomiec NA, Komotskaja VA. The application of the algorithm of the individualization of students' physical education process. Physical education of students, 2014; 18(6): 3-7. doi:10.15561/20755279.2014.0601

8. Olkhovy OM, Petrenko YM, Temchenko VA, Timchenko AN. Model of students' sport-oriented physical education with application of information technologies. Physical education of students, 2015; 19(3): 29-37. doi:10.15561/20755279.2015.0304

9. Vorob'eva VA. Vospitanie moral'nykh i volevykh kachestv studentov pedagogicheskogo vuza sredstvami basketbola [Education of moral-will qualities by basketball means in pedagogic HEE students]. Pedagogics, psychology, medical-biological problems of physical training and sports, 2005;10:17-19.

10.Konik GA, Temchenko VA, Usova TE. Sovremennye tendencii organizacii fizicheskogo vospitaniia studentov [Modern tendencies in organization of students' physical education]. Physical education of students, 2009;4:68-74.

11.Denisenko IA. The peculiarities of functional state changes of cardiovascular system of girls at the age 18-19 years in the process of practicing sport and health tourism. Physical education of students, 2013; 17(5): 32-36. doi:10.6084/ m9.figshare.781289

12.Barybina LN. Research overview of physical education individualization in higher education institution. Pedagogics, psychology, medical-biological problems of physical training and sports, 2012;9:14-18.

13.Iermakov SS, Ivashchenko PI, Guzov VV. Features of motivation of students to application of individual programs of physical self-preparation. Physical education of students, 2012;4:59-61.

14.Grygus IM, Kucher TV. Optimizing the level of the physical health of the students with a glance of the type of autonomic nervous system. Physical education of students, 2013; 17(3):
26-30. doi:10.6084/m9.figshare.662556

15.Kolumbet AN, Dudorova LYu. Methodic of perfection of higher pedagogical educational establishments girl students' rhythm. Physical education of students, 2016; 20(3): 4-12. doi:10.15561/20755279.2016.0301

16.Saluk IA. Individualizaciia fizichnogo vikhovannia studentiv z riznim rivnem zdorov'ia. Kand. Diss. [Individualization of physical education of students with different health level. Cand. Diss.], Kiev; 2010. (in Ukrainian)

17.Iackiv VS. Optimizaciia individual'noi fizichnoi pidgotovki students'koi molodi $\mathrm{v}$ aspekti gumanistichnikh cinnostej fizichnoi kul'turi [Optimization of students' individual physical training in the aspect of physical culture's humanistic values]. Visnik Chernigivs'kogo nacional'nogo pedagogichnogo universitetu, 2012;9(3):100-105. (in Ukrainian)

18.Kurmaeva EV. Fitness - programs as mean of forming of personality physical culture of students. Physical education of students, 2013; 17(1): 37-39. doi:10.6084/ m9.figshare. 156355

19.Sosnickij VN. Fizicheskaia podgotovka doprizyvnoj molodezhi s uchetom tipologii dvigatel'nykh sposobnostej. Kand. Diss. [Physical training of pre-conscription youth, considering typology of motor abilities. Cand. Diss.], Volgograd; 2000. (in Russian)

20.Kozina ZL, Iermakov SS. Analysis of students' nervous system's typological properties, in aspect of response to extreme situation, with the help of multi-dimensional analysis. Physical education of students, 2015; 19(3): 10-19. doi:10.15561/20755279.2015.0302

21.Muntian V.S. Fight-fitness in the program of student's physical education in higher educational institutions. Physical education of students, 2011;1:94 - 98. doi:10.6084/ m9.figshare.669670

22.Bartnovskay LA, Kudryavtsev MD, Kravchenko VM, Iermakov SS, Osipov AYu, Kramida IE. Health related applied technology of special health group girl students' physical training. Physical education of students, 2017; 21(1): 4-9. doi:10.15561/20755279.2017.0101

23.Drogomeretsky VV, Kopeikina EN, Kondakov VL, Iermakov SS. Adaptation of Ruffier's test for assessment of heart workability of students with health problems. Pedagogics, psychology, medical-biological problems of physical training and sports, 2017; 21(1): 4-10. doi:10.15561/18189172.2017.

24.Druz VA, Iermakov SS, Artemyeva GP, Puhach YI, Muszkieta R. Individualization factors of students' physical education at modern stage of its realization. Physical education of students, 2017; 21(1): 10-16. doi:10.15561/20755279.2017.0102

25.Druz VA, Iermakov SS, Nosko MO, Shesterova LYe, Novitskaya NA. The problems of students' physical training individualization. Pedagogics, psychology, medicalbiological problems of physical training and sports, 2017; 21(2): 51-59. doi:10.15561/18189172.2017.0201

26.Jagiello W. Differentiation of the body composition in taekwondo-ITF competitors of the men's Polish national team and direct based athletes. Archives of Budo. 2015;11:329-38.

27.Kalina RM, Jagiello W, Chodala A. The result of "testing fights in a vertical posture" as a criterion of talent for combat sports and self-defence - secondary validation (part I: the reliability). Archives of Budo Science of Martial Arts and Extreme Sports. 2015;11:229-38.

28.Larsson H, Nyberg G. "It doesn't matter how they move really, as long as they move.' Physical education teachers on developing their students' movement capabilities. Physical Education and Sport Pedagogy. 2017;22(2):137-49. 
29.Martin JT, Tubera JG, Monta VD, Naguiat ES, Yambao MJC, Tullao M, et al. Motivation and physical activity participation of Filipino college students. Asia Life Sciences. 2016;25(1):245-54

30.Osipov AYu, Kudryavtsev MD, Gruzinky VI, Kramida IE, Iermakov SS. Means of optimal body mass control and obesity prophylaxis among students. Physical education of students, 2017; 21(1): 40-45. doi:10.15561/20755279.2017.0107

31.Perez-Samaniego V, Fuentes-Miguel J, Pereira-Garcia S, Devis-Devis J. Abjection and alterity in the imagining of transgender in physical education and sport: a pedagogical approach in higher education. Sport Education and Society. 2016;21(7):985-1002.

32.Podrigalo LV, Galashko M N, Iermakov SS, Rovnaya OA, Bulashev AY. Prognostication of successfulness in armwrestling on the base of morphological functional indicators' analysis. Physical education of students, 2017; 21(1): 46-51. doi:10.15561/20755279.2017.0108
33.Pryimakov AA, Eider E, Nosko MO, Iermakov SS. Reliability of functioning and reserves of system, controlling movements with different coordination structure of special health group girl students in physical education process. Physical education of students, 2017; 21(2): 84-89. doi:10.15561/20755279.2017.0206

34.Reuker S. The noticing of physical education teachers: a comparison of groups with different expertise. Physical Education and Sport Pedagogy. 2017;22(2):150-70.

35.Stride A. Centralising space: the physical education and physical activity experiences of South Asian, Muslim girls. Sport Education and Society. 2016;21(5):677-97.

36.Svennberg L. Swedish PE teachers' understandings of legitimate movement in a criterion-referenced grading system. Physical Education and Sport Pedagogy. 2017;22(3):257-69.

Information about the author:

Andres A.S.: http: // orcid.org/0000-0002-1472-9009; andres_a@ukr.net; National University of Lviv's Polytehnyka, st. Samchuk, 14, Lviv, Ukraine.

Cite this article as: Andres AS. Physical education of students, considering their physical fitness level. Physical education of students, 2017;21(3):103-107. doi:10.15561/20755279.2017.0301

The electronic version of this article is the complete one and can be found online at: http://www.sportedu.org.ua/index.php/PES/issue/archive

This is an Open Access article distributed under the terms of the Creative Commons Attribution License, which permits unrestricted use, distribution, and reproduction in any medium, provided the original work is properly cited (http://creativecommons.org/licenses/by/4.0/deed.en).

Received: 08.02.2017

Accepted: 25.02.2017; Published: 10.05.2017 